\title{
Economic Valuation of Green Electricity Sources in Pakistan
}

\author{
Iqbal Muhammad-Jawad \\ School of Business and Economics, Universiti Putra Malaysia (UPM) \\ 43400 Serdang, Selangor, Malaysia \\ Tel: 92-333-781-8420Ｅ-mail: jawadiqbal828@hotmail.com
}

\author{
Abdul Samad Abdul-Rahim (Corresponding author) \\ School of Business and Economics, Universiti Putra Malaysia (UPM) \\ 43400 Serdang, Selangor, Malaysia
}

Tel: 603-9769-7654Ｅ-mail: abrahimabsamad@gmail.com

Received: May 19, 2020 Accepted: July 9, 2020 Published: July 16, 2020

doi:10.5296/ber.v10i3.17051 URL: https://doi.org/10.5296/ber.v10i3.17051

\begin{abstract}
Green electricity, which comes from renewable sources such as wind, hydro and solar, are well appreciated for their being environment friendly. The advantage of these sources are apparent in part of already natural environment. Moreover, this modern form of electricity also contributes in the poverty alleviation in developing countries, which is one of the sustainable development goals (SDG). The objective of this study is to explore electricity consumers' willingness to pay for the sustainable energy by employing the contingent valuation method (CVM). The respondents were divided into two broad categories of urban and rural consumers. A total of 400 respondents from urban and 405 respondents from rural areas were selected for this study. The CVM calculated the overall price of green electricity for the improvement of environment through increasing the share of electricity from renewable energy sources. The widely used WTP measure double-bounded dichotomous was utilised to elicit the appropriate value of green electricity from the bid price. The results from the logit regressions showed that the respondents with high income and a higher level of education are willing to pay more for green electricity in both urban and rural models. However, results also revealed that the willingness to pay for green electricity is high in younger people than older people. The mean willingness to pay has found 0.33 cents per $\mathrm{kWh}$
\end{abstract}


in the urban model, while is 0.24 in the rural model. The results provided a guideline to the government to charge an appropriate surcharge from the consumers in order to enhance the share of green electricity in energy mix.

Keywords: Sustainable energy, Green electricity, Renewable energy sources, Economic valuation, Contingent valuation method, Willingness to pay, Pakistan

\section{Introduction}

Electricity generated by fossil fuels refers to conventional energy means of non-renewable generation, having a bad impact on the environment and leads to climate change. However, world is facing worsening environmental change which requires a global attention to reduce carbon emissions (Choi, Ritchie, \& Fielding, 2016). In Pakistan, energy sector is one of the most prominent sector in $\mathrm{CO}_{2}$ emission. If the attention will not be given to the transition of this sector, it can contribute more in increasing emission in future. The energy sector can be transformed through dependence on local renewable energy sources for electricity generation which are in abundance in the country. The "green" electricity is generated from renewable energy sources. These sources can be solar, wind, hydro, geothermal and biomass which have no or very less harmful impact on the environment (Hansla et al., 2008).

Pakistan intends to reduce its dependence on energy imports by increasing the share of green electricity (electricity generated from renewable energy sources) through its indigenous sources. The government set the target of $5 \%$ of total generation from green energy sources by 2030 . The target is expected to gradually increase up to $15 \%$ after the said time limit. The government is not only investing in green energy projects through the technical and financial help of international institutions but as well as promoting private investors to invest in green electricity projects by removing taxes on imports of related items. The government also plans to allow private electricity generation firms to sale electricity directly to consumers in order to reduce burden on electricity distribution companies. The State Bank of Pakistan (SBP) is also supporting small scale power plants ( $4 \mathrm{KW}$ to $50 \mathrm{MW}$ ) by allowing commercial and development banks to provide loans for 10 to 12 years to the green energy power plants with $6 \%$ fixed interest rate. The government of Pakistan introduced net metering regulations on September 1, 2015, which allows consumers to sale their surplus electricity to the national grid up to a certain generation capacity. Moreover, Pakistan ratified the Paris agreement on November 11, 2016 (Climatescope Pakistan, 2017), which intends to reduce its 2030 projected Greenhouse Gas (GHG) emissions by up to $30 \%$ as per its Nationally Determined Contribution (NDC). This commitment is subject to the provision of international grants to meet the total abatement cost which the country estimates at about $\$ 40$ billion at current prices. Despite so many actions taken by the government, Pakistan is still unable to achieve its renewable energy targets due to issues such as lack of investment, delay of project implementations, unavailability of foreign investment, lack of public awareness and less public participation. This study aims to investigate the electricity consumers' knowledge, awareness, perception and willingness to pay for sustainable electricity in Pakistan. Therefore, we have decided to use a contingent valuation method (CVM) to investigate the perception, awareness, attitudes, and willingness to pay for green electricity of urban and rural population 
of Pakistan

The paper comprises of sections herewith are: section 2 discuss about the literature review and the genesis of the hypothesis of the study; section 3 describes the methodology of the study which takes account of variables and data collection; section 4 analyses the findings; section 5 accords with the conclusion and implication of the study along with limitations and directions for future study.

\section{Literature Review}

Nowadays, energy consumption accounts for $80 \%$ of $\mathrm{CO}_{2}$ emissions which are the major source of global warming and represent the most dangerous effects of climate change. Then, it is indisputable that any effort to effectively reduce $\mathrm{CO}_{2}$ emissions and mitigate climate change must include the energy sector (IEA, 2015).

Alves \& Uturbey (2010) stated that electricity generation especially from fossil fuels strongly contributes to environmental degradation which negatively impacted the environment and life on earth. These effects may be local or worldwide and the quality of air, water, soil and human health affects badly. Among the most important negative effects of electricity generation are global warming associated to greenhouse gases emissions and air pollution caused by particulate matter emissions.

Alam, Fatima, \& Butt (2007) emphasized on the environmental degradation due to human activities and stated that the Earth's climate is changing at an unprecedented rate with its wide-ranging future implications especially the security implications of changes in the natural environment. They further argued that the environmental degradation is also expected to have considerable impacts on natural resource systems, and thereby changes in the natural environment can affect human sustenance and economic activities. Moreover, in some previous studies like (Magazzino, 2014), the causal relationship found between electricity demand and GDP growth which shows the importance of electricity consumption in the economic growth. According to Magazzino (2017), the renewable energy is currently receiving policy support but the electric policies should be formulate in such a way that it can incorporate societal demands and avoid any political destabilization.

Green energy emerged as a clean source of energy after raising the concern over $\mathrm{CO}_{2}$ emission due to generation of electricity from fossil fuels. Though there are several studies have been done in Pakistan which used CVM but there is no study found regarding willingness to pay for green electricity. Some previous studies in this field are being discussed below.

Yang, (2013) as cited in (Yang, Solgaard, \& Haider, 2016) stated that research on consumers' preference for green electricity is growing rapidly in recent years. X. Guo et al., 2014, have investigated willingness of consumer's to pay for the green electricity in China. They employed contingent valuation method (CVM) and identified factors which influence willingness to pay for green electricity like Electricity consumption, income, knowledge and positive attitude. They found the average WTP for green electricity 2.7-3.3 US dollars (Rs 424-518) per month. They proposed a Green Electricity Fund (surcharge on electricity bill) 
in order to collect money to invest in green electricity projects. Lee \& Heo, (2016a) investigated the value of renewable electricity and obtained information on consumer preferences in 2014 in Korea. They employed contingent valuation method (CVM) to identify the consumer's green energy acceptance level and their additional WTP. Their results indicated that Korean consumers are willing to sacrifice an additional USD 3.21(Rs 504) monthly for green electricity. Zorić \& Hrovatin (2012) investigated the willingness to pay for green electricity in Slovenia by employing two models namely Tobit model and double-hurdle model and conducted an internet and field survey together in 2008. They examined customers' preferences in accordance with voluntary participation in green electricity programs. They also studied the determinants that influence the willingness to pay (WTP) for green electricity. They estimated average WTP as Euro 4.18 (Rs 727). They further stated that age, education, income level and environmental awareness are the key determinants in explaining household's attitudes towards green electricity. On the other hand, gender, household size, type of residence and location are found insignificant. Zografakis et al., (2010) conducted research in Crete about willingness to pay and acceptance regarding Renewable Energy Sources (RES). They employed contingent valuation method using a double bound dichotomous choice format. They found that the majority of households are interested towards the implementation of Renewable Energy Sources. Mean willingness to pay was found to be Euro17.88 (Rs 3111) per person per annum. They further suggested that marketing for renewable energy sources is necessary in order to increase the level of awareness among people with more emphasis on climate change and local issues in the region. Bigerna \& Polinori (2014) conducted research on environment and energy targets on Italy in year 2007. In the research, the CVM (Contingent Valuation Method) was applied to specifically investigate the Italian households' WTP to achieve the EU climate change policy through their willingness to pay (WTP) for Green Electricity, which can be a burden in shape of increasing electricity bill. They estimated median WTP between 4.62 EURO (Rs 803) and 8.05 EURO (Rs 1400) bimonthly per household. Moreover, Batley et al., (Batley et al., 2001) investigated WTP for the green electricity in the UK. They found 34\% of respondents were willing to pay $16.6 \%$ extra for green electricity. They also found the positive relationship between income and willingness to pay more for green electricity.

The public is usually found in favour of green energy all over the world and also willing to sacrifice some amount for the improvement of green electricity. However, there is varied opinion found in previous studies due to different scenarios of countries regarding climate change and other factors. It is therefore important that an assessment of people's willingness to pay, perception and knowledge about green electricity are better understood to formulate adequate policies and investment for future.

\section{Research Methodology}

\subsection{Scenario Formulation}

Scenario includes the most important part of the questionnaire. It was formulated on the basis of current circumstances of the climate change, environmental condition and energy status of the country. The respondents are the ordinary consumers of electricity; therefore, it is 
necessary to present the pros and cons of green electricity in comparison with the energy from fossil fuels. Further, the scenario also incorporated the details of the government plan for the improvement of green electricity, and how the consumers can help the government in order to increase the green energy.

\subsubsection{Scenario}

Increased burning of fossil fuels (Coal, oil, and gas) to meet the energy demand has not only resulted in the Greenhouse Gases (GHGs) emissions but also caused the global warming leading to climate change. This situation demands for exploring alternatives to fossil fuels for achieving targets of energy supply, security, and sustainability. In this context, the government Pakistan has been taking various measures, including restructuring of the electricity sector, developing future strategies, which ensures affordable and clean electricity with efficient generation, towards sustainable development in the country. Electricity from renewable sources (GREEN ELECTRICITY) require huge investments as government of Pakistan imposed 10 cents/kWh on monthly electricity bill for the construction of Neelum-Jhelum Hydro-power Project. However, in order to supply uninterrupted electricity, reduction in carbon emission and to combat with climate change in Pakistan, there is a dire need for more investment to generate electricity from renewable sources. In this regard, a survey is going to be conducted to assess the willingness to pay of people of Pakistan for electricity from renewable sources. On the top of the 10 cents $/ \mathrm{kWh}$, are you willing to contribute an extra amount of money so that the green electricity can be materialized?

Important: Your contribution will help the government to enhance the resources of green electricity and to minimize the dependency on imported fossil fuels.

\subsubsection{Model Specification}

$$
W T P_{i}=\beta_{0}+\beta_{1} P G E_{i}+\beta_{2} I N C_{i}+\beta_{3} E D U_{i}+\beta_{4} A G E_{i}+\beta_{5} G E N_{i}+\beta_{6} J O B_{i}+\beta_{7} E S T A T_{i}+\varepsilon
$$

where:

WTP = Probability of saying "yes" or "no" to the price

$\mathrm{PGE}=\mathrm{Bid}$ price for green electricity expressed in Pak Rupees (Rs)

$\mathrm{INC}=$ Consumers' monthly income expressed in Pak Rupees (Rs)

EDU $=$ Consumers' education level

$\mathrm{AGE}=$ Respondent's age in a year

GEN $=$ Respondent's Gender

$\mathrm{JOB}=$ Respondent's nature of Job

$\mathrm{ESTAT}=$ Worry about Energy Status

\subsection{Questionnaire Development and Methodology Used}

The design of the questionnaire was set up in such a way as the domestic consumers of 
electricity were asked to respond to it. The questionnaire was developed after the focus group discussion and pre-test procedure. All the errors and difficulties to understand had been removed before final survey. The questions regarding the WTP was the most important part of the CVM questionnaire. In this study, we have used double-bounded dichotomous choice questions in which, the respondents were twice presented in the questions about the prices. This technique is one of the best which allows better estimation results even with a small number of samples. The questions regarding perception, knowledge and awareness, and demographics also included in the questionnaire so that the factors of WTP can also be assessed.

\section{Results and Discussion}

A total of 400 urban and 405 rural respondents were interviewed. The respondents were selected through convenience sampling technique in both urban and rural clusters. The research took place from October 2018 to February 2019. Some important information regarding the respondent's level of knowledge and awareness, perception and demographics are presented in the following section.

\subsection{Descriptive Statistics}

This section includes information about the respondent's demographics including age, gender, level of formal education, occupational status and income. This section also takes account of the respondent's general knowledge, awareness, and concerns about energy status and climate change in Pakistan, as well as, their attitudes towards the use of green electricity.

\subsubsection{Respondent's Profile}

The respondents are categorized into two categories, i.e. rural and urban, who were electricity consumers of Lahore Electric Supply Company (LESCO). Both the respondents' categories were interviewed through questionnaires. 
Table 1. Demographic Profile of Urban and Rural Respondents

\begin{tabular}{|c|c|c|c|c|c|}
\hline \multirow[t]{2}{*}{ Variable } & \multirow[t]{2}{*}{ Category } & Urban & Rural & & \\
\hline & & Frequency & Percentage (\%) & Frequency & Percentage (\%) \\
\hline \multirow[t]{3}{*}{ Age } & 18-30years & 52 & $13.0 \%$ & 109 & $26.9 \%$ \\
\hline & $31-50$ years & 284 & $71.0 \%$ & 235 & $58.0 \%$ \\
\hline & 51 and Above & 64 & $16.0 \%$ & 61 & $15.1 \%$ \\
\hline \multirow[t]{2}{*}{ Gender } & Male & 343 & $85.8 \%$ & 396 & $97.8 \%$ \\
\hline & Female & 57 & $14.2 \%$ & 09 & $2.20 \%$ \\
\hline \multirow[t]{7}{*}{ Education Level } & No Education & 01 & $0.30 \%$ & 18 & $4.40 \%$ \\
\hline & Primary & 05 & $1.30 \%$ & 34 & $8.40 \%$ \\
\hline & Secondary & 04 & $1.00 \%$ & 80 & $19.8 \%$ \\
\hline & Matric & 12 & $3.00 \%$ & 113 & $27.9 \%$ \\
\hline & Inter & 38 & $9.50 \%$ & 101 & $24.9 \%$ \\
\hline & Bachelor & 132 & $33.0 \%$ & 48 & $11.9 \%$ \\
\hline & Master & 208 & $52.0 \%$ & 11 & $2.70 \%$ \\
\hline \multirow[t]{6}{*}{ Occupational Status } & Government & 58 & $14.5 \%$ & 24 & $5.90 \%$ \\
\hline & Private & 199 & $49.5 \%$ & 202 & $49.9 \%$ \\
\hline & Business & 122 & $30.5 \%$ & 172 & $42.5 \%$ \\
\hline & Student & 06 & $1.50 \%$ & 01 & $0.20 \%$ \\
\hline & Retiree & 06 & $1.50 \%$ & 03 & $0.70 \%$ \\
\hline & Housewife & 09 & $2.30 \%$ & 03 & $0.70 \%$ \\
\hline \multirow[t]{6}{*}{ Income } & Below Rs:20,000 & 21 & $5.30 \%$ & 31 & $7.70 \%$ \\
\hline & $20,001-40,000$ & 37 & $9.30 \%$ & 182 & $44.9 \%$ \\
\hline & $40,001-60,000$ & 39 & $9.80 \%$ & 109 & $26.9 \%$ \\
\hline & $60,001-80,000$ & 58 & $14.5 \%$ & 61 & $15.1 \%$ \\
\hline & $80,001-100,000$ & 107 & $26.8 \%$ & 22 & $5.40 \%$ \\
\hline & Above Rs:100,000 & 138 & $34.5 \%$ & 00 & $0.00 \%$ \\
\hline
\end{tabular}

Based on the information provided in Table 1, the age is divided into three categories which are 18 to 30 years, 31 to 50 years, and 51 and above. According to these three categories, 52(13\%) urban respondents lie into the first category, 284(71\%) respondents lie into the second category and 64(16\%) respondents lie into the third category. On the other hand, respondents from rural areas are 109(26.9\%), 235(58.0\%), 61(15.1\%) in the three categories respectively. The male and female ratio is $343(85.8 \%)$ and $57(14.2 \%)$ in urban; while $396(97.8 \%)$ and $09(2.20 \%)$ in rural respectively. Level of formal education is higher in urban areas, which also reflects in our sample. In the urban sample, bachelor and masters level are identified as the biggest group, which comprise of more than $80 \%$ of the urban sample. However, matric and inter level of education is identified as the biggest group of our sample, which comprise of almost $50 \% .14 .5 \%$ of the respondents are working in government in our urban sample, while $49.5 \%$ of respondents are working in private firms and $30.5 \%$ respondents do their own private businesses. In the rural sample, $5.90 \%$ are employed in government, almost $50 \%$ are from private firms and $42.5 \%$ are running their businesses. Income level is found higher in the urban respondents then rural. Income is categorized into sub six categories. According to the income categories, 5.30\%, 930\%, 9.80\%, 14.5\%, 26.8\% and $34.5 \%$ respondents lies in the first to sixth category in urban sample. However, $7.70 \%$, $44.9 \%, 26.9 \%, 15.1 \%$ and $5.40 \%$ respondents lie in the first to the fifth category in the rural sample. 
4.2 General Knowledge and Awareness of the Respondents about Green Energy

This section gives information about the respondent's general knowledge, awareness, attitudes and concerns about green energy.

Table 2. Knowledge about Solar energy

\begin{tabular}{|l|l|l|l|l|}
\hline \multicolumn{5}{|c|}{ Do you know energy can be produced by the sun? } \\
\hline & Urban & Rural & \\
\hline & Frequency & Percent (\%) & Frequency & Percent (\%) \\
\hline No & 10 & 2.5 & 46 & 11.4 \\
\hline Yes & 390 & 97.5 & 359 & 88.6 \\
\hline
\end{tabular}

According to the information provided in Table 2, 390 and 359 number of respondents in urban and rural respectively have affirmed 'yes' to the question and only 2.5 percent and 11.4 percent electricity consumers answered 'no' in urban and rural respectively. This shows that most of the respondents know about solar energy in Pakistan.

Table 3. Knowledge about wind energy

\begin{tabular}{|l|l|l|l|l|}
\hline \multicolumn{5}{|c|}{ Do you know energy can be produced by the wind? } \\
\hline & Urban & Rural \\
\hline & Frequency & Percent (\%) & Frequency & Percent (\%) \\
\hline No & 44 & 11.0 & 76 & 18.8 \\
\hline Yes & 356 & 89.0 & 329 & 81.2 \\
\hline
\end{tabular}

According to Table 3, 89\% urban and $81.2 \%$ rural respondents know that the electricity can be produced by wind source.

Table 4. Knowledge about Hydro

\begin{tabular}{|l|l|l|l|l|}
\hline \multicolumn{5}{|c|}{ Do you know energy can be produced by the flow of water? } \\
\hline & Urban & Rural \\
\hline & Frequency & Percent $(\boldsymbol{\%})$ & Frequency & Percent (\%) \\
\hline No & 18 & 4.5 & 37 & 9.10 \\
\hline Yes & 382 & 95.5 & 368 & 90.90 \\
\hline
\end{tabular}

According to the Table 4, 95.5\% urban and almost $90 \%$ of the rural respondents know that electricity can be produced by flow of water. The ratio of hydro is identified as the most popular source as per our sample because Pakistan is producing electricity from hydroelectric dams since the last few decades and this source is very common to the people of Pakistan.

A general question asked from the respondents of their level of knowledge about green energy, most of them lacked any knowledge or had inadequate knowhow thereon in both the urban and rural respondent categories. The details can be seen in Table 5. 
Table 5. Level of Knowledge about Renewables

\begin{tabular}{|l|l|l|l|l|}
\hline On Scale of 1 to 5 could you indicate what you think is your level of knowledge about renewable energies \\
\hline & Urban & Rural & \\
\hline & Frequency & Percent (\%) & Frequency & Percent (\%) \\
\hline I do not know anything & 30 & 7.4 & 27 & 6.8 \\
\hline I know little & 188 & 46.4 & 181 & 45.3 \\
\hline Average knowledge & 116 & 28.6 & 119 & 29.8 \\
\hline I know enough & 40 & 9.9 & 44 & 11 \\
\hline High knowledge & 31 & 7.7 & 29 & 7.2 \\
\hline
\end{tabular}

\subsection{Concerns about Energy Status and Climate Change in Pakistan}

Table 6. Concern about energy status in Pakistan

\begin{tabular}{|l|l|l|l|l|}
\hline \multicolumn{5}{|l|}{ How much you are worried about the energy status in Pakistan } \\
\hline & Urban & Rural & \\
\hline & Frequency & Percent (\%) & Frequency & Percent (\%) \\
\hline Little and not at all & 135 & 33.8 & 130 & 32.1 \\
\hline Much and very much & 265 & 66.3 & 275 & 67.9 \\
\hline
\end{tabular}

According to the information in Table 6, 66.3\% urban respondents and around 68\% rural respondent showed their serious concerns about the energy status in Pakistan. However, less than $35 \%$ respondents in both the cases showed their little or no concern about the energy status in Pakistan, which shows that most of the electricity consumers are more concerned about the energy status in Pakistan.

Table 7. Concerns about climate change in Pakistan

\begin{tabular}{|l|l|l|l|l|}
\hline \multicolumn{5}{|c|}{ Do you think climate change is an important problem for Pakistan } \\
\hline & Urban & Rural \\
\hline & Frequency & Percent (\%) & Frequency & Percent (\%) \\
\hline Little and not at all & 119 & 29.8 & 139 & 34.32 \\
\hline Much and very much & 281 & 70.3 & 266 & 65.67 \\
\hline
\end{tabular}

When the respondents were asked about their concerns on climate change, both the urban and rural consumers showed their serious concerns on climate change situation in Pakistan as the country is facing problems in energy security keeping in view the global climate change issues (Valasai et al., 2017). However, more than $70 \%$ of the urban sample and $65.67 \%$ of the rural samples have aspersions about the climate change situation in Pakistan.

\subsection{Perception about the Advantages and Disadvantages of Green Energy}

In this section, respondents were asked to give their opinion about the advantages and disadvantages of green energy so that we can get more insight into the consumer's perception of green energy. According to Table 8, when the respondents were asked about their views of the advantages and disadvantages of green energy, most of them had positive views about 


\section{$\triangle$ Macrothink}

renewable energy. When the respondents were asked the question i.e. green energy can be a cause to decrease the environmental impacts from the overexploitation and use of fossil fuels, $28.5 \%$ and $48.5 \%$ of the respondents of urban sample answers were in the scale of 'very important' and 'very much important'. On the other hand, respondents from the rural sample put low values than their counterpart urban sample and answered as $24.2 \%$ and $42 \%$ in the scale as 'very important' and 'very much important' to the same question. However, when both samples were asked to give value to the importance of renewable energy role on energy security of the country, both the samples had high values which are $27.5 \%$ and $53.5 \%$ for urban; and $27.2 \%$ and almost $54 \%$ for rural as 'very important' and 'very much important', respectively. Furthermore, on the question of reduction of oil dependence, $22 \%$ and $19 \%$ of urban and rural samples had it as 'very important' respectively. While more than $50 \%$ of the urban and rural samples put the reduction of oil dependence by green energy as 'very much important'. Almost $27 \%$ of urban and $20 \%$ of rural marked as 'very important' to the question related to the improvement of quality of life due to pollution reduction by renewables. More than $50 \%$ in both samples were of the view that this advantage is very much important in the context of Pakistan. Both the sample were uncertain about the creation of jobs due to renewable energy improvement but rural sample gave more value to this question due to the existing fewer employment facilities in the rural areas.

In case of disadvantages of renewable energy, both samples argued and valued that the renewable installation cost will be high, especially in the urban sample, where more than 51\% respondents perceived that the installation cost of green energy will be high. On the last disadvantage of the renewables, almost $50 \%$ of both the samples stated their views that the renewables like solar and wind depend upon the conditions of the weather, thus that can affect the generation which they answered as 'very much important.

Table 8. Perception about advantages and dis-advantages of green energy

\begin{tabular}{|l|l|l|l|l|l|l|l|l|l|l|}
\hline $\begin{array}{l}\text { Renewable } \\
\text { Energy }\end{array}$ & \multicolumn{2}{l}{$\begin{array}{l}\text { Very Little } \\
\text { Important }\end{array}$} & \multicolumn{2}{l}{$\begin{array}{l}\text { Little } \\
\text { important }\end{array}$} & \multicolumn{2}{l|}{ Neutral } & \multicolumn{2}{l|}{ Very Important } & \multicolumn{2}{l|}{$\begin{array}{l}\text { Very much } \\
\text { important }\end{array}$} \\
\hline & Urban & Rural & Urban & Rural & Urban & Rural & Urban & Rural & Urban & Rural \\
\hline Advantages & & & & & & & & & & \\
\hline $\mathbf{1}$ & $6.25 \%$ & $6.9 \%$ & $5.75 \%$ & $10.1 \%$ & $11.25 \%$ & $16.8 \%$ & $28.25 \%$ & $24.2 \%$ & $48.5 \%$ & $42.0 \%$ \\
\hline $\mathbf{2}$ & $3.50 \%$ & $3.7 \%$ & $7.25 \%$ & $7.4 \%$ & $8.25 \%$ & $8.1 \%$ & $27.5 \%$ & $27.2 \%$ & $53.5 \%$ & $53.6 \%$ \\
\hline $\mathbf{3}$ & $13.0 \%$ & $11.9 \%$ & $3.75 \%$ & $5.2 \%$ & $7.25 \%$ & $10.1 \%$ & $22.0 \%$ & $19.3 \%$ & $54.0 \%$ & $53.6 \%$ \\
\hline $\mathbf{4}$ & $5.50 \%$ & $5.9 \%$ & $7.25 \%$ & $13.3 \%$ & $7.75 \%$ & $9.6 \%$ & $26.75 \%$ & $20.5 \%$ & $52.75 \%$ & $50.6 \%$ \\
\hline $\mathbf{5}$ & $18.0 \%$ & $15.1 \%$ & $10.0 \%$ & $17.8 \%$ & $23.0 \%$ & $19.0 \%$ & $14.0 \%$ & $12.1 \%$ & $35.0 \%$ & $36.0 \%$ \\
\hline Dis-advantages & & & & & & & & & & \\
\hline $\mathbf{1}$ & $6.50 \%$ & $18.1 \%$ & $4.50 \%$ & $17.0 \%$ & $10.75 \%$ & $6.7 \%$ & $27.0 \%$ & $22.0 \%$ & $51.25 \%$ & $46.2 \%$ \\
\hline $\mathbf{2}$ & $8.75 \%$ & $11.1 \%$ & $6.25 \%$ & $9.9 \%$ & $9.50 \%$ & $11.4 \%$ & $25.75 \%$ & $18.0 \%$ & $49.75 \%$ & $49.6 \%$ \\
\hline
\end{tabular}

\subsection{Attitudes towards Green Energy}

In this section, the respondents were asked about their attitudes towards the use of green energy. The urban respondents were found very much in favour of the consumption of green energy. However, their rural counterparts showed less favourability. This is because the rural population has fewer income resources than the urban population so their attitudes are 
according to the economic theory that high income leads to a high willingness to pay and vice versa. Further details can be seen in Table 9 below.

Table 9. Attitudes towards the use of green energy

\begin{tabular}{|c|c|c|c|c|}
\hline \multirow{2}{*}{$\begin{array}{l}\text { Although the economic costs of production are } \\
\text { higher, are you in favor or against the use of } \\
\text { renewable energy? }\end{array}$} & \multicolumn{2}{|l|}{ Urban } & \multicolumn{2}{|l|}{ Rural } \\
\hline & Frequency & Percent & Frequency & Percent \\
\hline Very against & 43 & $10.8 \%$ & 54 & $13.3 \%$ \\
\hline Against & 30 & $7.5 \%$ & 116 & $28.6 \%$ \\
\hline Neither in favor nor against & 50 & $12.5 \%$ & 53 & $13.1 \%$ \\
\hline In favour & 102 & $25.5 \%$ & 63 & $15.6 \%$ \\
\hline Very much in favour & 175 & $43.8 \%$ & 119 & $29.4 \%$ \\
\hline
\end{tabular}

\subsection{Contingent Valuation Method Analysis}

In this section, the results from the contingent valuation method (CVM) will be presented. The CVM method used for the analysis and to compute the overall amount of electricity consumers' willingness to pay for the electricity generated from the renewable energy sources. $64.00 \%$ of the urban sample was willing to pay and contribute to the improvement of green electricity, while $36.00 \%$ of the sample were unwilling to pay any extra dime. On the other hand, the ratio for willing to contribute any extra amount has been decreased and $43.70 \%$ of the rural sample were willing to pay and contribute for the improvement of green electricity, while $56.30 \%$ of the sample were disinclined to pay any extra amount. The above-mentioned information is given in Table 10.

Table 10. Response to the probability of willingness to pay

\begin{tabular}{|l|l|l|l|l|}
\hline \multirow{2}{*}{ Response } & Urban & \multicolumn{2}{l|}{ Rural } \\
\cline { 2 - 5 } & Frequency & Percent (\%) & Frequency & Percent (\%) \\
\hline Yes & 256 & 64.00 & 177 & 43.70 \\
\hline No & 144 & 36.00 & 228 & 56.30 \\
\hline Total & 400 & $100 \%$ & 405 & $100 \%$ \\
\hline
\end{tabular}

Further, the information regarding each bidding price in percentage is given in Table 11. The bid price is offered 10 cents to 50 cents per unit of electricity consumption. The percentage reveals that the higher the price of a bid, the lower the willingness to pay, which is an expected finding in contingent valuation studies. Moreover, information about all the bids is also available in detail in Table 12 for rural sample and Table 13 for the urban sample with percentages in parenthesis. 
Table 11. Response to offered Bid price

\begin{tabular}{|l|l|l|l|l|}
\hline \multicolumn{4}{|l|}{ Willingness to Pay (\%) } \\
\hline \multirow{2}{*}{ Bid price } & Urban & \multicolumn{2}{l|}{ Rural } \\
\cline { 2 - 5 } & Yes & No & Yes & No \\
\hline 10 Cents & 77.44 & 22.56 & 60.90 & 39.10 \\
\hline 20 Cents & 70.68 & 29.32 & 45.86 & 54.14 \\
\hline 30 Cents & 63.91 & 36.09 & 45.11 & 54.89 \\
\hline 40 cents & 57.46 & 42.54 & 40.29 & 69.71 \\
\hline 50 Cents & 32.84 & 67.16 & 17.27 & 82.73 \\
\hline
\end{tabular}

Table 12. Rural Frequency classified by Bid values (Percentages in Parenthesis)

\begin{tabular}{|l|l|l|l|l|l|l|}
\hline $\begin{array}{l}\text { Questionnaire } \\
\text { version }\end{array}$ & $\begin{array}{l}\text { Bid values } \\
\text { [Initial:Upper:Lower] }\end{array}$ & YY & YN & NY & NN & Total \\
\hline $\mathbf{1}$ & {$[20: 30: 10]$} & $30(22.56)$ & $31(23.31)$ & $51(38.35)$ & $21(15.79)$ & 133 \\
\hline $\mathbf{2}$ & {$[30: 40: 20]$} & $33(24.81)$ & $27(20.30)$ & $17(12.78)$ & $56(42.11)$ & 133 \\
\hline $\mathbf{3}$ & {$[40: 50: 30]$} & $22(15.83)$ & $34(24.46)$ & $03(2.16)$ & $80(57.55)$ & 139 \\
\hline
\end{tabular}

Table 13. Urban Frequency classified by Bid values (Percentages in Parenthesis)

\begin{tabular}{|l|l|l|l|l|l|l|}
\hline $\begin{array}{l}\text { Questionnaire } \\
\text { version }\end{array}$ & $\begin{array}{l}\text { Bid values } \\
\text { [Initial:Upper:Lower] }\end{array}$ & YY & YN & NY & NN & Total \\
\hline $\mathbf{1}$ & {$[20: 30: 10]$} & $69(51.88)$ & $25(18.80)$ & $34(25.56)$ & $05(3.76)$ & 133 \\
\hline $\mathbf{2}$ & {$[30: 40: 20]$} & $20(15.04)$ & $65(48.87)$ & $08(6.02)$ & $40(30.08)$ & 133 \\
\hline $\mathbf{3}$ & {$[40: 50: 30]$} & $41(30.60)$ & $36(26.87)$ & $03(2.24)$ & $54(40.30)$ & 134 \\
\hline
\end{tabular}

After that, we adopted a follow up question for those respondents who answered in negation to both the bids. We kept it open so that they may state any amount for green electricity improvement. This is done for locating the free riders who want improvement in green electricity. Moreover, we later asked the electricity consumers to state their reason why they were reluctant to pay for green electricity improvement. Once again the urban and rural respondents acted differently. Most of the urban sample stated that the cost of green electricity is higher and they don't have enough money to contribute. On the other hand, most of the rural sample stated that the government should do something about the improvement of green electricity. The further details can be seen in Tables 14 and 15.

Table 14. Urban respondent's reason for not willing to pay for green electricity

\begin{tabular}{|l|l|l|}
\hline Reason & Frequency & Percentage \\
\hline I don't have enough money to contribute & 107 & 26.75 \\
\hline I am not sure that there will be any improvement by paying extra & 77 & 19.25 \\
\hline Green electricity cost is higher & 110 & 27.5 \\
\hline Government and other agencies should do something for improvement & 59 & 14.75 \\
\hline Others & 47 & 11.75 \\
\hline
\end{tabular}


Table 15. Rural respondent's reason for not willing to pay for green electricity

\begin{tabular}{|l|l|l|}
\hline Reason & Frequency & Percentage \\
\hline I want to contribute for green electricity but I don't have money & 95 & 23.46 \\
\hline Government should do something for green electricity improvement & 151 & 37.28 \\
\hline Already expensive & 87 & 21.48 \\
\hline Others & 72 & 17.78 \\
\hline
\end{tabular}

In the next question as to who should be responsible for the development of green electricity, the urban sample were of the view that government, private power producers and consumers are almost equally responsible for the improvement of green electricity. However, most of the rural sample stated that the government is responsible for the development of green electricity.

\subsection{Empirical Results Double-Bounded Logit Model}

The double-bounded dichotomous technique has been employed by using STATA version 15 . The independent variables to describe the variation in the dependent variable were carefully chosen based on the implication of economic theory and findings from past studies. All variables statistical significance have been evaluated. Table 16 shows the results of the final model including urban and rural sample.

Table 16. Regression results double-bounded model

\begin{tabular}{|l|l|l|l|l|}
\hline \multirow{2}{*}{ Variables } & \multicolumn{2}{|l|}{ Double-bounded (Urban) } & \multicolumn{2}{l|}{ Double-bounded (Rural) } \\
\cline { 2 - 5 } Constant & Coefficient & Standard Error & Coefficient & Standard Error \\
\hline AGE & 0.150 & 0.097 & 0.118 & 0.092 \\
\hline GENDER & -0.002 & $0.001 *$ & -0.004 & $0.001^{*} * *$ \\
\hline JOB & 0.008 & 0.026 & -0.011 & 0.071 \\
\hline EDUCATION & 0.019 & $0.009 *$ & -0.002 & 0.014 \\
\hline INCOME & 0.050 & $0.012^{*} * *$ & 0.031 & $0.011^{*} *$ \\
\hline ESTAT & 0.044 & $0.007 * * *$ & 0.056 & $0.017^{*} * *$ \\
\hline No of Respondents & 0.035 & 0.018 & 0.060 & $0.026^{*}$ \\
\hline Log-likelihood & 400 & & 405 & \\
\hline Pseudo R & -466.859 & -488.838 & \\
\hline
\end{tabular}

Note: *Significant at $10 \% ; * *$ Significant at $5 \%$; *** Significant at $1 \%$

According to Table 16, all variables are significant except gender and energy status (estat) in urban model. However, variable gender is also insignificant in the rural final model but the variable "energy status" is significant here.

The age variable in the urban model is $10 \%$ significant while it is $1 \%$ significant in the rural model. In both models, the coefficient is found negative which reveals that the willingness to pay for the green electricity is high in the younger people than the older people in both the models. According to Oerlemans, Chan, \& Volschenk (2016) most of the studies related to green electricity have reported a negative relationship between age and willingness to pay. 
Moreover, the negative sign is also confirmed from the previous renewable electricity related studies (Dagher \& Harajli, 2015) and (Jihyo Kim, Park, Kim, \& Heo, 2013).

The variable occupation is significant only in urban model with a positive sign and $10 \%$ level of significance. On the other hand, it is insignificant in the rural sample with the negative coefficient which can be related to the previous study of (Dagher \& Harajli, 2015). However, our focus is only on the significant variables like occupation in urban sample which is significant and shows that better job condition is related to the higher willingness to pay. According to Batley et al., (2001), willingness to pay varies the level of income and social status. In urban areas, the status is mostly defined by the nature of job. So we can deduce that better job condition is an important variable for willingness to pay for green electricity. Additionally, people who are working on a better position, they also need good environmental conditions and are worried about the clean environment surrounding them. Therefore, these people are willing to pay more for green electricity.

The variable for education has a positive sign and is significant at $1 \%$ and $5 \%$ level in urban and rural models respectively. Oerlemans et al., (2016) also stated in their review paper regarding green electricity that most of the previous related studies have stated a positive and significant relationship between education level and willingness to pay. Further, Junghun Kim, Park, \& Lee (2018) also found a significant and positive relationship with education and preference for green energy. Our results are also consistent with the studies of (Zarnikau, 2003), who also found a significant and positive relationship with education and willingness to pay.

Income is the only variable which is equally $1 \%$ significant in both the urban and rural samples. The variable also has a positive relationship which shows that with the increase in income, willingness to pay also increases. People with a high level of income are willing to contribute more for the green electricity. Our results are also consistent with the previous studies of (Zarnikau, 2003) and (Wiser, 2007).

Energy status (estat) is positively related but not significant in urban sample. However, this variable is positively related and is $10 \%$ level significant in rural sample, which shows that people who are more worried about the energy status of Pakistan are willing to pay higher for green energy improvement. Rural areas are more affected with the electricity cut off in peak seasons than the urban areas. People of the rural sample are more worried about energy status of Pakistan and willing to pay more for its improvement. Our results are also consistent with the previous studies of (Zografakis, 2010).

\subsection{Willingness to pay (WTP) estimation for CVM}

The estimated mean willingness to pay for double -bounded is given in Table 17. Mean willingness to pay for the green electricity in the urban sample is RS 0.33 cents and in rural sample, the mean WTP is RS 0.24 cents per unit of electricity consumption. 
Table 17. Willingness to pay mean value

\begin{tabular}{|l|l|l|}
\hline \multirow{2}{*}{} & \multicolumn{2}{|l|}{ Mean Willingness to Pay } \\
\cline { 2 - 3 } & Urban & Rural \\
\hline Double-bounded & 0.33 & 0.24 \\
\hline
\end{tabular}

Further, to calculate the approximate additional net benefit or overall contribution of the electricity consumers of LESCO region for the improvement of green electricity, it can be calculated by multiplying mean willingness to pay with the annual electricity consumption. According to the latest report published by National Electric Power Regulatory Authority (NEPRA), the overall annual average consumption of LESCO's consumers is given in Table 18. We can calculate the overall net benefit for the improvement in green electricity year wise from the values given in Table 18. Further calculation for the net benefit is given in Table 19.

Table 18. Annual electricity consumption

\begin{tabular}{|l|l|l|l|l|l|l|l|l|}
\hline \multicolumn{2}{|l|}{ Average Annual Electricity Consumption per Connection (kWh) in LESCO } \\
\hline Year & Domestic & Commercial & Industrial & Agricultural & $\begin{array}{l}\text { Public } \\
\text { Lighting }\end{array}$ & $\begin{array}{l}\text { Bulk } \\
\text { Supply }\end{array}$ & Others & $\begin{array}{l}\text { Overall } \\
\text { Average }\end{array}$ \\
\hline $\mathbf{2 0 1 2 - 1 3}$ & 1895.05 & 2184.2 & 83387.67 & 17969.54 & 48540.4 & 872678.9 & 23561.64 & 3991.03 \\
\hline $\mathbf{2 0 1 3 - 1 4}$ & 2056.62 & 2315.79 & 90298.51 & 19655.4 & 47734.4 & 908024.4 & 30762.33 & 4295.74 \\
\hline $\mathbf{2 0 1 4 - 1 5}$ & 2028.89 & 2276.02 & 89130.66 & 18568.91 & 42370.9 & 957122.4 & 32109.7 & 4176.2 \\
\hline $\mathbf{2 0 1 5 - 1 6}$ & 2121.32 & 2499.42 & 86648.24 & 20351.06 & 41740.8 & 1049775.5 & 34481.33 & 4223.3 \\
\hline $\mathbf{2 0 1 6 - 1 7}$ & 2294.19 & 2736.35 & 75617.96 & 20054.3 & 39265.68 & 1153830.6 & 29959.35 & 4156.84 \\
\hline
\end{tabular}

Source: State of industry report Nepra 2017

Table 19. Estimation of Net benefit

\begin{tabular}{|c|c|c|c|c|c|c|}
\hline \multirow[b]{2}{*}{ Year } & \multicolumn{3}{|l|}{ Urban } & \multicolumn{3}{|l|}{ Rural } \\
\hline & $\begin{array}{l}\text { Number of } \\
\text { Consumers } \\
\text { (million) }\end{array}$ & $\begin{array}{l}\text { Average electricity } \\
\text { consumption }\end{array}$ & $\begin{array}{l}\text { Expected } \\
\text { Net Benefit }\end{array}$ & $\begin{array}{l}\text { Number of } \\
\text { Consumers } \\
\text { (million) }\end{array}$ & $\begin{array}{l}\text { Average electricity } \\
\text { consumption }\end{array}$ & $\begin{array}{l}\text { Expected } \\
\text { Net Benefit }\end{array}$ \\
\hline 2012-13 & 2.36 & 2634.08 & 6.2 Billion & 1.21 & 1356.95 & 1.6 Billion \\
\hline 2013-14 & 2.45 & 2835.188 & 6.9 Billion & 1.26 & 1460.552 & 1.8 Billion \\
\hline 2014-15 & 2.58 & 2756.292 & 7.1 Billion & 1.32 & 1419.908 & 1.8 Billion \\
\hline 2015-16 & 2.71 & 2787.378 & 7.5 Billion & 1.39 & 1435.922 & 2 Billion \\
\hline 2016-17 & 2.82 & 2743.514 & 7.7 Billion & 1.45 & 1413.326 & 2 Billion \\
\hline
\end{tabular}

\section{Conclusions and Policy Recommendation}

The results of this study provide several policy recommendations for the policy-makers in the country. The key results of chapter 4 proposed that the respondents are willing to pay as an overall amount for the improvement of green electricity is 0.33 and 0.24 for urban and rural, respectively. According to the demographic differences, this clearly shows that people with low or few sources of income, low level of education are willing to pay less for green electricity in both the models. Therefore, the first policy recommendation that may be 
presented to the government is that to implement or impose minimum charges in the name of "GREEN ELECTRICITY SURCHARGE" on all the electricity consumers to improve the share of green electricity in the electricity mix of the country. However, the government may impose green electricity surcharge in two ways; first is to impose any fixed amount according to the tariff categories of the consumers. Secondly, the surcharge may be imposed on the basis of consumption of electricity. The most important thing is to keep in mind while implementing any policy regarding it is that the consumers who are using more electricity or whose usage is high, is contributing more in the air pollution, so these types of consumers should be charged a higher amount.

It has been also noticed that knowledge and awareness of the renewable energy and its impact on the environment and relation with climate change also made a huge effect on the willingness to pay for green energy. Therefore, the government should spread awareness about the usefulness of green electricity among the common masses, through it is electricity distribution companies, media and through other sources. By this way, the demand for green electricity will increase in the grass-root level, which ultimately positively result in the future.

Moreover, the government should formulate energy policies keeping in mind the cost effectiveness, address multiple development objectives and avoid political destabilization in future so that the targets of green electricity improvement can be achieved.

\section{References}

Alam, S., Fatima, A., \& Butt, M. S. (2007). Sustainable development in Pakistan in the context of energy consumption demand and environmental degradation. Journal of Asian Economics, 18(5), 825-837. https://doi.org/10.1016/j.asieco.2007.07.005

Alves, L. A., \& Uturbey, W. (2010). Environmental degradation costs in electricity generation: The case of the Brazilian electrical matrix. Energy Policy, 38(10), 6204-6214.

https://doi.org/10.1016/j.enpol.2010.06.006

Batley, S. L., Colbourne, D., Fleming, P. D., \& Urwin, P. (2001). Citizen versus consumer: Challenges in the UK green power market. Energy Policy, 29(6), 479-487. https://doi.org/10.1016/S0301-4215(00)00142-7

Bigerna, S., \& Polinori, P. (2014). Italian Households' Willingness to Pay for Green Electricity. Renewable and Sustainable Energy Reviews, 34, 110-121.

https://doi.org/10.1016/j.rser.2014.03.002

Choi, A. S., Ritchie, B. W., \& Fielding, K. S. (2016). A Mediation Model of Air Travelers' Voluntary Climate Action. Journal of Travel Research, 55(6), 709-723.

https://doi.org/10.1177/0047287515581377

Climatescope Pakistan. (2017). [Online] Available:

http://global-climatescope.org/en/policies/\#/policy/4075

Dagher, L., \& Harajli, H. (2015). Willingness to pay for green power in an unreliable electricity sector: Part 1. The case of the Lebanese residential sector. Renewable and 
Sustainable Energy Reviews, 50, 1634-1642. https://doi.org/10.1016/j.rser.2015.04.162

Guo, X., Liu, H., Mao, X., Jin, J., Chen, D., \& Cheng, S. (2014). Willingness to pay for renewable electricity: A contingent valuation study in Beijing, China. Energy Policy, 68, 340-347. https://doi.org/10.1016/j.enpol.2013.11.032

Hansla, A., Gamble, A., Juliusson, A., \& Gärling, T. (2008). Psychological determinants of attitude towards and willingness to pay for green electricity. Energy Policy, 36(2), 768-774. https://doi.org/10.1016/j.enpol.2007.10.027

IEA. (2015). CO2 emissions from fuel combustion highlights. [Online] Available: https://www.iea.org/subscribe-to-data-services/co2-emissions-statistics

Kim, J., Park, J., Kim, J., \& Heo, E. (2013). Renewable electricity as a differentiated good? The case of the Republic of Korea. Energy Policy, 54, 327-334. https://doi.org/10.1016/j.enpol.2012.11.042

Kim, J., Park, S. Y., \& Lee, J. (2018). Do people really want renewable energy? Who wants renewable energy?: Discrete choice model of reference-dependent preference in South Korea. Energy Policy, 120(September 2017), 761-770. https://doi.org/10.1016/j.enpol.2018.04.062

Lee, C.-Y., \& Heo, H. (2016). Estimating willingness to pay for renewable energy in South Korea using the contingent valuation method. Energy Policy, 94, 150-156.

https://doi.org/10.1016/j.enpol.2016.03.051

Magazzino, C. (2014). Electricity demand, GDP and employment: Evidence from Italy. Frontiers in Energy, 8(1), 31-40. https://doi.org/10.1007/s11708-014-0296-8

Magazzino, C. (2017). Stationarity of electricity series in MENA countries. Electricity Journal, 30(10), 16-22. https://doi.org/10.1016/j.tej.2017.11.014

Oerlemans, L. A. G., Chan, K. Y., \& Volschenk, J. (2016). Willingness to pay for green electricity: A review of the contingent valuation literature and its sources of error. Renewable and Sustainable Energy Reviews, 66, 875-885. https://doi.org/10.1016/j.rser.2016.08.054

Valasai, G. Das, Uqaili, M. A., Memon, H. U. R., Samoo, S. R., Mirjat, N. H., \& Harijan, K. (2017). Overcoming electricity crisis in Pakistan: A review of sustainable electricity options. Renewable and Sustainable Energy Reviews, 72(November 2016), 734-745.

https://doi.org/10.1016/j.rser.2017.01.097

Wiser, R. H. (2007). Using contingent valuation to explore willingness to pay for renewable energy: A comparison of collective and voluntary payment vehicles. Ecological Economics, 62(3-4), 419-432. https://doi.org/10.1016/j.ecolecon.2006.07.003

Yang, Y. (2013). Perspective on Marketing of Green Electricity (PhD Thesis). Faculty of Social Science, University of Southern Denmark: University Press of Southern Denmark.

Yang, Y., Solgaard, H. S., \& Haider, W. (2016). Wind, hydro or mixed renewable energy source: Preference for electricity products when the share of renewable energy increases. Energy Policy, 97, 521-531. https://doi.org/10.1016/j.enpol.2016.07.030 


\section{Macrothink}

Business and Economic Research ISSN 2162-4860 2020, Vol. 10, No. 3

Zarnikau, J. (2003). Consumer demand for ' green power' and energy efficiency. Energy Policy, 31, 1661-1672.

Zografakis, N., Sifaki, E., Pagalou, M., Nikitaki, G., Psarakis, V., \& Tsagarakis, K. P. (2010). Assessment of Public Acceptance and Willingness to Pay for Renewable Energy Sources in Crete. Renewable and Sustainable Energy Reviews, 14(3), 1088-1095.

https://doi.org/10.1016/j.rser.2009.11.009

Zorić, J., \& Hrovatin, N. (2012). Household willingness to pay for green electricity in Slovenia. Energy Policy, 47, 180-187. https://doi.org/10.1016/j.enpol.2012.04.055

\section{Glossary}

$\mathrm{CO}_{2}$ - Carbon Dioxide

CVM - Contingent Valuation Method

GDP - Gross Domestic Products

GHG - Greenhouse Gases

KWh: Kilowatt Hours

WTP - Willingness to Pay

\section{Copyright Disclaimer}

Copyright for this article is retained by the author(s), with first publication rights granted to the journal.

This is an open-access article distributed under the terms and conditions of the Creative Commons Attribution license (http://creativecommons.org/licenses/by/4.0/). 